\title{
GRANDPARENTS AND CONTACT: 'RIGHTS V WELFARE’ REVISITED
}

\section{FELICITY KAGANAS AND CHRISTINE PIPER*}

On 5 June 2000 the US Supreme Court declared, in Troxel v Granville, ${ }^{1}$ that a Washington grandparent visitation statute infringed parental rights under the US Constitution.Three days later, in the Family Division of the English High Court, Mr Justice Wall, referring to the European Convention on Human Rights - albeit in the different context of contact with children in care- seemed to be dismayed at the prospect of the court being faced with similar rights-based appeals: His Lordship said he would be 'disappointed' if the Convention were to be 'routinely paraded in cases of this nature as makeweight grounds of appeal'. ${ }^{2}$ Nevertheless he did anticipate that the Court of Appeal would be required to make general rulings in relation to particular articles of the Convention. Indeed, in an earlier case - Re W(Contact application: procedure) ${ }^{3}$ the judge had predicted that the Convention would be used in the context of grandparent contact disputes.

It is, then, apparently an issue, on both sides of the Atlantic, whether rights deriving from constitutional codes and rights conventions can, and should, be used (successfully) in disputes between parents and extended family members about the children of the family. This issue has become more important given that the role of the extended family is an area of growing policy interest in both countries, not least because of the political need to attract the 'grey' vote. In the UK, media interest appears to have been stimulated by the publication of a government consultation paper, Supporting Families (Home Office, 1998).

* Centre for the Study of Law, the Child and the Family, Law Department, Brunel University. 


\section{SUPPORTING THE FAMILY}

Supporting Families, prepared by a specially constituted Ministerial Group on the Family, asserts that the government, 'recognising the role of the wider family, and particularly grandparents' (Home Office, 1998: para 1.45), plans to cast them as key players in initiatives to support 'the family' and to strengthen communities. In an effort to counter the tendency for the interests and contributions of extended family members to be 'marginalised' by service providers, the government states its intention to introduce policies - in education, social services, housing and health - that will promote and facilitate 'a positive role' for 'grandparents - and other relatives ... in their families’ (para 1.60).

Yet while the document stresses the importance of grandparents, that importance is presented as lying primarily in the contribution they might make to the stability and survival of the 'traditional' or nuclear family consisting only of parent(s) and child(ren). ${ }^{4}$ Grandparents, volunteer substitute grandparents and other extended family members will be a multi-faceted resource: they will bridge the gaps between families and schools and families and communities, will look after related children on behalf of social services, will be a source of 'social and cultural history' (1998: 18-19) to give the community roots, will act as mentors 'for young people whose parents are not able to provide a stable and supportive home environment' (1998: 16-17), and will be a ready source of help to their families living nearby. ${ }^{5}$ The emphasis is, then, on kin as a practical resource and as a vehicle for transmitting the values and knowledge seen as necessary for the stability of communities through the raising of well-adjusted and responsible citizens. ${ }^{6}$ In so far as legislation may ensue, it will encourage professionals to use the extended family to provide benefits for children and their parents at home, at school and in the community. 
What the document does not address is the situation inherent in Troxel v Granville and Re W, where, most commonly after the breakdown of the parents' relationship, there is conflict between the nuclear and the extended family and the involvement of extended family members is unwanted. The document does not propose new remedies for those who feel excluded. Nor does it challenge the assumption that 'family' equals 'parent(s) plus child(ren)'. It is likely to be limited in effect, therefore, in comparison with changes introduced in other jurisdictions such as South Africa ${ }^{7}$ and Macedonia, ${ }^{8}$ for example, where the law has gone some way towards extending the concept of the 'family'.

\section{EXCLUDING FAMILY}

Whilst exclusion from the nuclear family may affect a variety of extended family members it is grandparents - on both sides of the Atlantic - who have been most vocal in articulating their exclusion as a problem and who have set up pressure groups to seek redress, notably the Grandparents Federation and Age Concern in the UK. Not only is the cohort of grandparents growing in numbers, ${ }^{9}$ its members also appear to be experiencing more difficulty in maintaining relationships with their grandchildren, ${ }^{10}$ partly because of the increased incidence of divorce. In the UK the Grandparent Federation has recently highlighted problems in relation to the operation of both public and private family law.

In regard to public law, they have criticised an apparent reluctance by social services to promote contact with grandchildren in care or to consider grandparent fostering of such grandchildren. They have compiled and published collections of personal stories from grandparents who have been excluded by social services from the lives of their grandchildren (Tingle, undated) and from 
grandparents who have been looking after their grandchildren but have failed to receive sufficient emotional or financial support from social services (Grandparents Federation, undated). That problem is addressed in Supporting Families in so far as the paper draws attention to the fact that a grandparent 'may provide a very effective placement' for a child 'looked after' by social services and invites views on 'best practice for grandparents as foster carers'. (Home Office, 1998: 18-19). And already, according to the findings of one research project, placements with grandparents are the most common extended family placements. ${ }^{11}$

It is the other main issue highlighted by the Grandparents Federation that is the one with which we are primarily concerned.This is the perception that many grandparents are denied contact with their grandchildren by parents and that they are prejudiced within the private law arena by the fact that they have no special status. A study exploring the experiences of members of the Grandparents Federation (Drew and Smith, 1999) reports problems such as the cost of legal proceedings and the detrimental impact of litigation on the family as impediments to the use of the courts. But there were also grandparents who complained about what they regarded as unfairness in the determination of contact disputes. Also, there were complaints about the reluctance of the judiciary to enforce those contact orders that are granted. Part of the difficulties experienced by grandparents, say the researchers, stems from the fact that the caretaking parent is 'generally believed by the courts to ... be the best judge of what is in the best interests of the child' and the court will 'accept this parent's recommendation to allow the child to see their grandparent or not' (1999: 212).

Of course, interviewees affiliated to a grandparents' pressure group are likely to be those experiencing the most severe kinds of difficulties and, moreover, the research gives no indication 
of rates of success among those grandparents in the sample who did go to law to seek contact orders. ${ }^{12}$ Nevertheless, the Grandparents Federation believes the extent of dissatisfaction with the operation of the provisions in the Children Act $1989^{13}$ is significant. Their director of policy has been reported as asserting that grandparents have few rights and that the organisation is seeking a change in the UK's domestic legislation, notably to give a right to apply without leave. ${ }^{14}$ In the light of available research, however, it is difficult to establish how the 'rights' already available under the Children Act 1989 are operating in practice in relation to grandparents.

\section{The Children Act 1989}

In the UK, lobbying in the 1980s led to the inclusion of provisions to widen access to the courts by 'non-parents' ${ }^{15}$ At the same time, grandparents lost any preferential legal status ${ }^{16}$ and must apply to the court, under section 10(9) of the Act, for leave to apply for section 8 orders (for contact and residence, inter alia). Of the three relevant criteria, it was believed that the second criterion $^{17}$ - 'the applicant's connection with the child' (section 10(9)(b)) - in particular would lead to courts giving grandparents ‘special consideration’ (Douglas and Lowe, 1990: 105), a view shared by the Lord Chancellor and the Minister of Health at the time of the passage of the Act. ${ }^{18}$ Whether this has occurred is not clear. On the one hand there is judicial acceptance of the idea that contact with grandparents is normally in the best interests of the child. For example, in Re W(Contact: Application by Grandparent), Hollis J asserted that grandparents 'have a very great place to play in the life of children, particularly young children ... This influence can be extremely beneficial to children, provided it is exercised with care and not too frequently'. ${ }^{19}$ On the other hand, whilst 'it can be in the best interests of a child to maintain contact with grandparents, even if there is parental opposition', ${ }^{20}$ there is evidence that this is not (always) the 
judicial approach.

Because of a current dearth of empirical data on the operation of the relevant statutory provisions, one can only review reported cases in relation to the main criticisms made by the Grandparents’ Federation. First, in relation to seeking leave to apply, the applicant must have ‘an arguable case’ (Hayes and Williams, 1999: 94-5). Re A and $W^{21}$ makes it clear that, although the child's welfare is not paramount in applications for leave, ${ }^{22}$ courts must engage in assessments of the child's welfare ${ }^{23}$ in establishing whether the grounds for leave have been satisfied. In this exercise the third criterion - 'any risk there might be of that proposed application disrupting the child's life to such an extent that he would be harmed by it' (section 10(9)(c)) may carry most weight, even though the definition of 'harm' is the restrictive one contained in section 31(9) of the Children Act $1989 .{ }^{24}$ Certainly, in one reported case in the Family Division, ${ }^{25}$ the judge dismissed an appeal against the decision of a stipendiary magistrate who had refused leave because of the ‘total opposition' of the parents to the child's contact with her paternal grandmother.

The second set of Grandparent Federation criticisms focuses on the substantive hearing where grandparents face a major difficulty because there is no presumption in English case law (as there is in effect in relation to natural parents) that contact should be awarded. Currently grandparents have to show grounds for contact; ${ }^{26}$ they are not in a 'special position, ${ }^{27}$ and the hearing will focus on the welfare of the child. ${ }^{28}$ However, it is again unclear how 'best interests' tend to be constructed when applications under sections 8 and 10 are precipitated by parental opposition to such contact. In In Re S (Contact: Grandparents), ${ }^{29}$ Wall J (as he then was) both found the mother's hostility to be unreasonable and endorsed the views of a clinical 
psychologist that the child was likely to suffer 'significant harm' if contact were not reestablished. ${ }^{30}$ Other reported cases, while relatively small in number, suggest that judges may be hesitant to award contact in the face of parental opposition and family conflict ${ }^{31}$ or, perhaps, in cases where there has been little contact in the past. ${ }^{32}$ Certainly Butler-Sloss LJ (now President of the Family Division) was clear in $R e A$ that the judge at first instance was right to deny grandparent contact 'at this stage' on account of intra-family conflict because time was needed before contact would be possible: '[B]ecause the grown ups cannot get on he cannot see the other family. He is entitled to both families but it requires the grown-ups to grow up ... and make it possible for this little boy to move between the two families' ${ }^{33}$

What limited evidence there is suggests that the judiciary is ambivalent about grandparent contact though in reported cases on residence ${ }^{34}$ there is a much clearer prioritisation of children's relationships with parents over those with grandparents. Moreover, it appears that this ambivalence may be shared by professionals involved in contact disputes. A decade ago it was found that mediators and divorce court welfare officers considered grandparent-grandchild contact valuable but rarely actively promoted it because of concerns about 'interfering' grandparents and about creating intra-family conflict (Kaganas and Piper, 1990). More recent research conducted by one of us suggests that solicitors are also ambivalent in relation to grandparent involvement. Of thirty-six solicitors interviewed, only three said they `always’ asked new divorce clients about grandparent contact and while the remaining solicitors 'sometimes' asked about this issue, only two said they asked because it was `in the child's best interests' whereas four solicitors expressed negative views about grandparents. They said that hostile grandparents `can brainwash children’, that grandparents `became polarised’ and that, where both sets of grandparents were closely involved, it `can make things a lot worse' ${ }^{35}$ 
Whilst we do not know what advice solicitors are now giving members of extended families who wish to institute contact proceedings, we do know that very few such relatives litigate: BaileyHarris et al found that out of 345 cases in their sample, only 6\% involved applications from grandparents and 4\% from others (1998: 18). Given Drew and Smith’s findings (1999: 205) and what we know of judical and professional thinking, it is probable that grandparents are not being encouraged to use what rights they already have and that stronger legal rights may therefore make little difference in practice. Nevertheless, lobbying on behalf of grandparents has taken the form of demands for greater rights.

\section{BETTER RIGHTS BASED REMEDIES?}

It has now been suggested that the Human Rights Act 1998 (HRA) will have profound implications for families ${ }^{36}$ and, specifically, might prove 'helpful to those wishing to challenge the ways that courts and local authorities deal with ... care proceedings, adoption, the rights of other relatives to access to the child (and vice versa)' (Wadham and Mountfield, 1999: 97). It might be seen as potentially opening up new avenues for grandparents in the UK to seek redress. Yet while this legislation might be a new resource for grandparents, it might equally prove useful for parents. This potential is highlighted by cases such as Troxel $v$ Granville in the USA where challenges have been mounted against those statutes which give grandparents standing to apply for access without any preconditions such as death or divorce of the parent(s). ${ }^{37}$

The HRA incorporates into the domestic law of the UK most of the rights and liberties enshrined in the European Convention on Human Rights. Among these is the right to respect for private and family life and the prohibition against unwarranted interference with these rights embodied 
in Art 8. The question which then arises is whether - and how - rights might make a difference if grandparents were to seek to rely in domestic courts on their right to family life in order to gain or maintain contact with their grandchildren. Given that the current law on contact places the child's best interests at the centre of decision-making, will rights 'work' to enhance grandparent status and to facilitate success in contact disputes? Even if parents - or children - do not invoke the same rights to resist such efforts, will rights prevail over constructions of the child's best interests that currently appear to disadvantage grandparents?

\section{'Rights $v$ welfare'}

Apparent in academic commentary on the HRA is an implicit or explicit assumption that there is a tension between a welfare and a rights based approach. An article - entitled 'The Human Rights Act and the welfare principle in family law - conflicting or complementary?' (Herring, 1999a) ${ }^{38}$ - refers to the tension 'between the wish to promote the welfare of the child and the concern to protect the rights of family members' and argues that, 'in the light of the Human Rights Act and the centrality of the welfare principle in the Children Act, the courts are going to be forced to develop some kind of synthesis between the two approaches' (1999a: 224). Elsewhere, it has been suggested that European case law recognising adults' independent rights to family life makes it difficult 'to rely on the child-centred conceptualisation of contact under the Children Act' (Bainham, 1995:258). Furthermore, a text on the HRA also summarises the approach under the Convention as 'different from that adopted by English law', and asserts that 'Article 8 does not support the notion that paramountcy is to be given to the interests of the child' (Swindells et al, 1998: para3.154).

This apparent resurgence of a 'rights $\mathrm{v}$ welfare' paradigm is surprising, given theoretical 
critiques of welfare and rights-based ‘justice’ as amorphous concepts with meanings contingent on context, ${ }^{39}$ the development of theories which reconceptualise welfare and justice as constructs within self-referential systems, ${ }^{40}$ and the emergence of practices of restorative justice and family mediation which transcend or bypass notions of welfare and rights. We now have a situation where a growing reification of inter-disciplinarity within the family justice system and the increasing importance of particular shared understandings of what should count as the best interests of the child have led to a corresponding reluctance by legal professionals to use legal remedies and rights. Conversely, advocates of children's rights take an inherently protectionist, welfare stance. $^{41}$

Perhaps the current assumption that a polarity exists is understandable, given that the rightsbased approach of the HRA - framed as it is within the libertarian tradition represented by the European Convention on Human Rights - is a completely new area of practice and study for many academics and professionals. The assumption that the new must also be different is fortified by some of the comments being made in recent texts. For example, Sedley LJ. in his 'Foreword' to a book on human rights law (Starmer, 1999) writes of the need 'for courts and lawyers to begin to acquire a new mindset' if the HRA is to be 'more than window-dressing' . ${ }^{4}$

However, the predicted clash between rights and welfare under the HRA may never materialise, at least not within the sphere of private family law. ${ }^{43}$ The rights enshrined in the European Convention, and so too in the HRA, are designed primarily to protect individual liberties against the depredations of an oppressive state, while also seeking to ensure that the state provides positive safeguards for those liberties. Their significance in resolving private family disputes is open to some doubt. The jurisprudence of the European Court of Human Rights ('the Court') and 
the (recently abolished) European Commission, we shall argue, neither polarises rights and welfare nor significantly extends the notion of 'the family'.

\section{GRANDPARENTS AND 'FAMILY LIFE’}

The crucial article for our purposes is Article 8 of the ECHR which provides:

1. Everyone has the right to respect for his private and family life, his home and his correspondence.

2. There shall be no interference by a public authority with the exercise of this right except such as is in accordance with the law and is necessary in a democratic society in the interests of national security, public safety or the economic well being of the country, for the prevention of disorder or crime, for the protection of health or morals, or for the protection of the rights and freedoms of others.

Whilst the precise nature of the rights protected under Art 8 has never been articulated, ${ }^{44}$ the Court has ruled that Art 8 does impose a positive obligation on the State: 'it must act in a manner calculated to allow those concerned to lead a normal family life' ${ }^{45}$ A claim that legislation should accord special status to particular categories of relatives such as grandparents would fall under Art 8(1) while the actions of state bodies that impede the exercise of the right to family life would fall under Art 8(2).

The first stage in determining in any particular case whether there has been a contravention of Art 8 is to decide whether the person alleging violation - in our case a grandparent - has a right to family life within the meaning of the Convention. It is well established that a right to family life exists between biological parents and their children - whether or not the parents are married. ${ }^{46}$ 
The Court has said, for example, that, in the case of married or cohabiting parents, the birth of a child immediately gives rise to a family bond amounting to family life (although the tie may be broken by subsequent events). ${ }^{47}$ The Court has also held that 'the mutual enjoyment by parent and child of each other's company constitutes a fundamental element of family life’ ${ }^{48}$

However, it is more difficult to show that the right to family life of either grandparents or grandchildren encompasses the maintainance of the relationship between them. The Court held, in the Marckx case, that " "family life", within the meaning of Article 8, includes at least the ties between near relatives, for instance, those between grandparents and grandchildren, since such relatives may play a considerable part in family life' ${ }^{49}$ The 'family life' referred to in the Convention, said the Court, embraces ‘social, moral or cultural relations' as well as interests 'of a material kind' such as inheritance rights. ${ }^{50}$ But, as Liddy points out (1998: 19), when it comes to disputes regarding the relationships between individuals, such as those between grandparents and parents over children, as opposed to issues relating to property or inheritance, no assumption is made that family life exists automatically as a function of blood ties; the Commission has interpreted and applied the Marckx case restrictively. There must be evidence of some form of actual family life between grandparents and grandchildren; to establish family life, close relatives have to show a close link in the nature of a relationship of dependency. ${ }^{51}$ It has accordingly been held that in the case of a grandparent who has taken on the care of a grandchild, the requirements of 'family life' are satisfied. ${ }^{52}$ A close relationship created by frequent contact also suffices. $^{53}$

Even if such a relationship is established, however, the issue of parental opposition is potentially fatal to an application because of the Court's stance on parental authority. As Harris et al 
observe, '[t]he positions of members of a family with respect to one another are not identical. In particular, the idea of family life acknowledges some authority of parents over young children’ (1995:316). So, for example, in Nielsen $v$ Denmark $^{54}$ the Court affirmed that the exercise of parental rights, including the authority to decide where the child should live and what constraints might be put on his or her liberty, 'constitutes a fundamental element of family life'. ${ }^{55}$ Reviewing the case law, Harris et al suggest that it raises implicitly the possibility that parents are deemed to have the 'right to control the personal relationships ... of their children' (1995: $317) .{ }^{56}$

Two cases ${ }^{57}$ dealing with access to children in local authority care also affirm parental authority, stating that access by grandparents to grandchildren is normally at the discretion of parents. However, as against the local authority, denial to the grandparent of 'the reasonable access necessary to preserve a normal grandparent-grandchild relationship, ${ }^{58}$ could constitute interference with family life. These cases could be interpreted as suggesting that 'normal' ties between grandparents and grandchildren are only those that meet with parental approval; the right to family life does not include the right to thwart parental authority. Alternatively, and in the light of the clear view ${ }^{59}$ that grandparents' rights are inferior to those of parents, a more plausible interpretation might be that grandparents' rights would carry less weight than those of parents at the second stage of the decision-making process.

\section{JUSTIFYING (NON-)INTERFERENCE}

Once the existence of the right has been established, the second stage involves a determination of whether that right has been violated, either by a failure to respect it (Art 8(1)) or by interference with it (Art 8(2)). If it is found that there has been interference, it will then have to be decided 
whether that interference is justified. This it will be if it is 'in accordance with the law', in pursuance of a ‘legitimate aim’ and ‘necessary in a democratic society’ (Liddy, 1998: 16). Case law of the Court and the Commission states that the notion of necessity should be read as indicating that interference is justifed if it corresponds to a 'pressing social need' and if it is 'proportionate to the legitimate aim pursued' ${ }^{60}$ This doctrine of proportionality is used to ensure that a 'measure imposes no greater restriction upon a Convention right than is absolutely necessary to achieve its objectives’ (Lord Irvine of Lairg, 1998: 233). Even if a grandparent, then, is able to establish a right to family life with his or her grandchildren, the Court, in proceeding to the next step, may find either that there has been no interference with this right or that interference is justified.The right to protection against interference is qualified and any consideration or prioritisation of the welfare of the child can easily be interpreted as being consistent with the protection of the child's health. The decisions of the Commission and the Court reveal that they consider that the legitimate aim of protecting the health and rights of others extends to the aim of safeguarding the welfare of a child, including the emotional and psychological well-being of that child. ${ }^{61}$

For example, in Johansen v Norway ${ }^{62}$ the Court referred to the need to strike 'a fair balance' between the interests of the parents and the child. In doing so, it said, 'the court will attach particular importance to the best interests of the child, which depending on their nature and seriousness may override those of the parent. In particular ... the parent cannot be entitled under Art 8 of the Convention to have such measures taken as would harm the child's health and development'. Similarly, the Court in Hokkanen v Finland ${ }^{63}$ stated that although a parent might have custody and access rights, 'Where contacts with the parent might appear to threaten [the child's] interests or interfere with those rights, it is for the national authorities to strike a fair 
balance between them'. ${ }^{64}$ Further, it seems that the interests of the community as a whole must also be put in the scales. ${ }^{65}$

In $K$ and $T v$ Finland ${ }^{66}$ the court made it clear that 'consideration of what is in the best interest of the child is in every case of crucial importance. And in deciding that restrictions on access did not violate Art.8, the court reached its findings 'in the light of the present-day interests of the children' ${ }^{67}$ In addition, the Court indicated in Glaser $v$ UK ${ }^{68}$ that while Art.8 creates obligations to take measures to reunite families, this obligation is not absolute; the rights and freedom of all concerned must be taken into account and, in particular, the best interests and rights of the child. Most significantly, perhaps, is the fact that a reading of Hokkanen suggests that, of all the interests weighed in the balance, those of the child were accorded priority, even to the extent that her wishes were determinative.The Court did decide that the parent's rights had been infringed by the failure of the authorities to enforce access but this finding was made in the context of a Court of Appeal judgment that contact with the applicant was in the child's best interests. ${ }^{69}$ But when the child grew mature enough for her wishes to be taken into account and articulated, her antipathy towards access, the court said, meant it was no longer a violation of Art 8 to fail to enforce it. Also, the Court had no hesitation in finding that a transfer of custody to the grandparents was 'necessary in a democratic society' in the light of expert opinion pointing to the 'length of the girl's stay with [them], her strong attachment to them and her feeling that their home was her own ${ }^{, 70}$.

Despite, therefore, the rights-based approach of the Convention and the need to balance conflicting rights, in practice the tendency of the Court has been to find interference with Art 8 rights legitimate provided the interference has been consistent with the child's welfare.The cases 
where interference has been found to be contrary to Art 8 have tended to involve a failure by child welfare authorities, absent any justification in terms of child welfare, ${ }^{71}$ to consult parents or a failure to give effect to court orders made in the child's interests. ${ }^{72}$ Whilst, therefore, the requirement that grandparents seek leave before applying for a section 8 order under the Children Act 1989 could be challenged under Art 8, such a challenge could well fail: the requirement could be seen as consistent with the need to consider the rights of the nuclear family and the welfare of the child. The mechanism of requiring leave is almost certainly proportionate to a legitimate aim of identifying meritorious claims. In McMichael v United Kingdom ${ }^{73}$ the Court held that a statutory mechanism for for the purpose of identifying meritorious fathers who might then be accorded parental rights was justified by the legitimate aim of protecting the rights of mothers and children. ${ }^{74}$ In addition this mechanism respected the principle of proportionality.

Whether the leave requirement contravenes Art 6 is also open to question. It appears that the right of access to a court is not absolute (Swindells et al, 1999: para 8.48). Limitations in pursuit of a legitimate aim, which satisfy the proportionality test and which do not impair the very essence of the right may be compatible with Art $6 .^{75}$

A challenge to the leave requirement, a claim by grandparents for special statutory status or a claim by parents that grandparents should not statutorily be permitted to seek contact would have to be taken to Strasbourg. Direct challenges to legislation do not fall within the purview of the Human Rights Act 1998, with which we are primarily concerned, and it is to this statute that we now turn.

\section{THE HUMAN RIGHTS ACT 1998}


When the HRA is implemented, it will be unlawful ${ }^{76}$ for a public authority to act in a way that is incompatible with a Convention right ${ }^{77}$ unless, as a result of the provisions of primary legislation, it could not have acted differently. ${ }^{78}$ The courts have a duty ' $[\mathrm{s}]$ o far as it is possible to do so', ${ }^{79}$ to interpret legislation in a way that is compatible with the Convention. And since the court is itself a public authority, ${ }^{80}$ it appears likely that the wording of the statute, coupled with the doctrine of 'horizontal effect', will be thought to require courts, in private disputes, also to develop the common law in accordance with the principles of the Convention (Laws, 1998: 263). ${ }^{81}$ This will affect all cases, whether in public or private law, against private individuals or public authorities, irrespective of whether the court is concerned with statutory construction, a declaration of common law or the exercise of judicial discretion (Wadham and Mountfield, 1999: 27). ${ }^{82}$ In the event of an unlawful act by a court of first instance, a litigant's remedy under section 9 lies in an appeal or judicial review (Wadham and Mountfield, 1999: 46). Where it is not possible to interpret legislation in accordance with the Convention, under section 4(2), a superior court may make a 'declaration of incompatibility'.

Any court or tribunal determining a question that has arisen in connection with a Convention right must take into account the jurisprudence of the European Court of Human Rights, of the Commission and of the Council of Ministers. ${ }^{83}$ It is not entirely clear, however, whether this jurisprudence will be imported wholesale ${ }^{84}$ because the European decisions are not intended to be binding on domestic courts. ${ }^{85}$ Nevertheless, it appears to be likely that courts will use concepts such as 'pressing social need' and the doctrine of proportionality, particularly in cases involving conflicting claims of right (Laws, 1998: 258, 262 and 265).

So, to return to the focus of this article, might it be possible for members of the extended family 
such as grandparents in dispute over contact, relying on European jurisprudence, to argue, provided they have had a close relationship with their grandchildren, that their right to family life encompasses contact? ${ }^{86}$

\section{Contact and family life}

There are three different scenarios that could arise ${ }^{87}$ if the link between grandparents and child is found to fall within the purview of family life. First, it could be argued by the grandparent, or child, that the absence of a presumption that contact is in children's best interests constitutes a failure to respect family life. This possibility was canvassed by Wilson $\mathrm{J}$ in $\operatorname{Re} W$ (Contact Application: Procedure): 'I anticipate that, when the Human Rights Act 1998 comes into force, it will be argued that a child's respect for his or her family life under Art 8 of the Convention requires the absence of such a presumption in the case of a grandparent to be revisited ${ }^{88}$ The difficulty with this argument would be, perhaps, that it presupposes that in a significant majority of cases, ${ }^{89}$ grandparent contact is indeed in children's best interests, a contention that has hitherto not been substantiated; available research offers qualified support for grandparent contact. $^{90}$

Second, grandparents could argue that for a court to refuse leave to apply for contact or to refuse contact itself constitutes an unlawful act. ${ }^{91}$ Section 3 of the HRA, which obliges courts to interpret legislation, where possible, in conformity with Convention rights has been described as ‘a deeply mysterious provision posing various problems of interpretation’ (Marshall, 1998: 167). It can probably be assumed that it will be read as requiring courts to assign a meaning to statutory provisions that best upholds Convention rights. Nevertheless its application to section 10 of the Children Act 1989 and to disputes over Children Act section 8 orders remains 
problematic.

As noted above, applications for leave to apply for section 8 orders must be decided in accordance with the statutory criteria embodied in s10(9) coupled with the welfare checklist in s1(3) though the child's welfare, it appears, is not the paramount consideration. ${ }^{92}$ Since neither s1(3) nor s10(9) is exhaustive, the court might be able to read into them a duty to consider the rights to family life of the various family members: grandparents, parents and children. ${ }^{93}$ The court in such a situation could, however, be confronted with a conflict of rights which would, it seems, have to be resolved by invoking the doctrine of proportionality ${ }^{94}$ and attempting to strike a fair balance. This could help to justify a decision to allow leave where, for example, it would result in some disruption for the parents but the nature of the relationship between grandparent and grandchild is close; it could be argued that the legitimate aim of safeguarding a child's rights or the child's mental, emotional or physical 'health' ${ }^{95}$ or welfare requires this incursion into parental rights. Conversely, it could be argued in a case where the disruption to the parents is great, that refusal of leave satisfies the proportionality test in the pursuit of the legitimate aim of safeguarding the rights of the child and parents as well as the child's health or welfare which, it could be contended, is best served by protecting the nuclear family from interference. ${ }^{96}$

When it comes to deciding substantive disputes about contact, as opposed to leave, the court, it seems, has less leeway. It must apply the Children Act 1989 checklist and has a statutory obligation to make the child's welfare paramount. ${ }^{97}$ The effect of the paramountcy principle is summed up in the oft quoted words of Lord Mac Dermott in $J v C .^{98}$ The statutory formula, he said: 
connote[s] a process whereby, when all the relevant facts, relationships, claims and wishes of parents, risks, choices and other circumstances are taken into account and weighed, the course to be followed will be that which is most in the interests of the child's welfare as that term has now to be understood. That is the ... paramount consideration because it rules upon or determines the course to be followed.

On the face of it, we do have here a clear 'rights v welfare' clash: the paramountcy principle could be said to be inconsistent with Art 8 of the Convention because it automatically renders the rights claims of the adults concerned subservient to the welfare of children and so might preclude the attainment of a 'fair balance'. ${ }^{99}$ Arguably, it would not, therefore, be possible for a court to read section 1 of the Children Act to give effect to either parents’ or grandparents’ rights to family life. This, almost certainly, would be the view of Swindells et al who question 'how parental rights can be subordinated to the interest of the child under the welfare paramountcy test' in the light of Convention law (1998: para 8.24), a view that would, arguably, necessitate a declaration of incompatibility. ${ }^{100}$ Yet the paramountcy principle could well be seen as necessary in a democratic society for the purpose of achieving a legitimate aim, that of protecting the health, ${ }^{101}$ and even the rights, of children, both because of their vulnerability and because their well-adjustment is crucial to the future of society. A fair balance, it seems, requires the consideration of harm to children. And, like the decisions of the European Court, domestic courts are, it could be said, justified in allowing children’s interests to tip the balance. ${ }^{102}$

A similar approach could be adopted in addressing the third scenario. It could be argued that a failure by a court to enforce an existing contact order through the mechanism of contempt proceedings is unlawful. This might be countered with the contention that committal 
proceedings, with the possible outcome of imprisonment, would lead to interference with the family life of parents and children and that, on balance, these rights or interests outweigh those of grandparents. And certainly the ECHR has taken the view that coercive measures to enforce contact orders should be circumspectly applied. ${ }^{103}$ The Court of Appeal in this jurisdiction has indicated, in the context of a dispute between parents, that committal should be seen only as a last resort: the power 'exists only to serve the ends of justice and ultimately the crucial consideration remains what the interests of justice in the broadest sense demand, giving p roper weight to the interests of the children even if their welfare is not strictly the paramount consideration' ${ }^{104}$ Nor did the public administration of justice require committal in cases heard in chambers. ${ }^{105}$ In the light of the negative effect committal of the mother would have on the children and on their relationship with their absent father, the court struck out the committal application. Thus it is apparent that, even when not paramount, children's interests may tip the balance, a result that is also consistent with European jurisprudence.

\section{A 'WIN' FOR WELFARE?}

The domestic courts have already turned their attention to the relationship between the paramountcy principle and the rights conferred by Art 8. In Dawson v Wearmouth, ${ }^{106}$ Lord Hobhouse of Woodborough said that nothing in the Convention requires the courts to act otherwise than in accordance with the interests of the child. The courts do recognise the existence of independent parental rights: in Re J (Specific Issue Orders: Muslim Upbringing and Circumcision), ${ }^{107}$ Wall J, in the context of Art 9 of the Convention, accepted that parents have rights under it $^{108}$ and in Re KD (A Minor)(Ward: Termination of Access), ${ }^{109}$ Lord Oliver accepted that a parent has a 'substantive right of access to his child'. Nevertheless Lord Oliver asserted that this is a 'right which will always be overborne if the interests of the child so 
dictate'. ${ }^{110}$ To quote him at length:

I do not, for my part, discern any conflict between the propositions laid down ... in $J \vee C$ and the pronouncements of the European Court of Human Rights in relation to the natural parents' [sic] right of access to her child. Such conflict as exists is, I think, semantic only and lies only in differing ways of giving expression to the single common concept that the natural bond and relationship between parent and child gives rise to universally recognised norms which ought not to be gratuitously interfered with and which, if interfered with at all, ought to be so only if the welfare of the child dictates it. .... Parenthood, in most civilised societies, is generally conceived of as conferring on parents the exclusive privilege of ordering, within the family, the upbringing of children of tender age, with all that entails.That is a privilege which, if interfered with without authority, would be protected by the courts, but it is a privilege circumscibed by many limitations .... When the jurisdiction of the court is invoked for the protection of the child the parental privileges do not terminate. They do, however, become immediately subservient to the paramount consideration which the court has always in mind, that is to say the welfare of the child. ${ }^{111}$

This approach was endorsed by Ward LJ in Re $P^{112}$ but Herring (1999a) contends that Lord Oliver was wrong to characterise the difference between the two approaches as merely semantic; the nature of the questions asked under each as well as the evidence required differs. ${ }^{113}$ However, given the willingness of the European institutions to prioritise children's welfare, the jurisprudence of those institutions is not clearly contradicted by the paramountcy principle. Even in $W \mathrm{v}$ United Kingdom (Denial of access to children taken into public care) ${ }^{114}$ the European 
Court of Human Rights, while asserting that parents' rights are independent of children's interests, appeared to be able to reconcile this principle with the paramountcy of children's welfare. Fortin (1999b) suggests that, while the rights of a party might be infringed by a decision concerning contact, as long as the decision is made in the child's best interests, it would automatically comply with Art 8(2). ${ }^{115}$

It appears that the UK judiciary is doing all that it can to keep welfare paramount. However a recent decision of the Court of Appeal ( $R v$ Secretary of State for Home Department Ex Parte Gangadeen: $R v$ Secretary of State for Home Department Ex Parte Khan) ${ }^{116}$ has, according to Swindells et al (1999: para 3.153), thrown into doubt the compatibility of the paramountcy principle with Art 8. Reviewing the decisions of the Commission and the European Court, the Court of Appeal concluded that both bodies approach the application of Art 8 'as a straightforward balancing exercise, in which the scales start even...; thus they do not support the notion that paramountcy is to be given to the interests of the child' ${ }^{117}$ Yet this approach might be explained by the fact that this case, and those European authorities ${ }^{118}$ cited by the court, all involved immigration disputes where the rights and interests of the individuals concerned were weighed against the right of the state 'to control the entry of non-nationals into its territory' ${ }^{119}$ As Swinton Thomas LJ stated in Gangadeen, '[i]n the field of immigration, particularly decisions relating to deportation, the interests of the child are not, and cannot, be paramount or primary ... If it were otherwise, it would be difficult ever to make a deportation decision in relation to a child, ${ }^{120}$

The Ganagadeen decision leaves open, therefore, the possibility that, while Art 8 does not support the application of the paramountcy principle in immigration cases where the state has a 
significant interest, it does not preclude the application of the principle in cases involving private disputes about children's upbringing. That being so, the incorporation of Art 8 into domestic law will, we suggest, make little difference in relation to grandparent contact disputes. The jurisprudence of the ECHR emphasises the nuclear family and the rights of parents to make decisions. Whilst the involved grandparent - those, for instance who have passed the ECHR 'actual family relationship test' - may have rights, these, it seems, are likely to be superseded by the superior rights of parents. What can tip the balance is the placing in the scales of the child's rights and welfare. So, what we are left with is a paradox. On the one hand, the HRA appears to make rights-talk central to family law. On the other hand, as we have seen, while rights hover in the background, courts filter these through the concept of welfare.

\section{FIT PARENTS DECIDE}

Our conclusion that rights deriving from the ECHR will not lead to new remedies for grandparents or to different conceptions of the family should come as no surprise, given the Troxel v Granville decision with which we began. This recent Supreme Court decision also highlights the importance accorded to the parents' interpretation of the child's best interests. The majority of the Supreme Court found that the application of s26.10.160(3) of the Washington Revised Code violated the mother's due process right under the Fourteenth Amendment - as decided in Meyer v Nebraska 67 L Ed 390 (1922) ${ }^{121}$ - to make decisions concerning the care, custody and control of her daughter.

The statutory provision in question permitted 'any person' to petition for visitation rights at 'any time' and authorised the court to grant visitation wherever it served the best interests of the child. The Supreme Court affirmed that it was 'breathtakingly broad', allowing any third party 
to instigate a state-court review in which 'a parent's decision that visitation would not be in the child's best interest is accorded no deference'. As O’Connor, J went on to explain, 'in practical effect, in the State of Washington a court [could] disregard and overturn any decision by a fit custodial parent ... based solely on the judge's determination of the child's best interests'; that could lead to the infringement of a parent's right, given the presumption, explained in Parham, that 'the natural bonds of affection lead parents to act in the best interests of their children',122 except when the parent is judged to be unfit. ${ }^{123}$ The visitation provision as applied was unconstitutional.

This could be seen as a victory for parental rights over either the welfare of the child or the rights of grandparents: Thomas, J., concurring, said that the case had been resolved 'by this Court's recognition of a fundamental right of parents' and Souter, J. added that there was no need to consider 'the precise scope of the parent's right or its necessary protections'. The mechanism used, however, was the reconstructing of parental autonomy rights as welfare: the court cites cases where the presumption was established that visitation is not in the child's best interests if parents oppose visitation. ${ }^{124}$ The judgement also leaves many questions unanswered because the court saw no need to consider

'whether the Due Process Clause requires all non-parental visitation statutes to include a showing of harm or potential harm to the child as a condition precedent to granting visitation. We do not, and need not, define today the precise scope of the parental due process right in the visitation context.... because much state-court adjudication in this context occurs on a case-by-case basis, we would be hesitant to hold that specific nonparental visitation statutes violate the Due Process Clause as a per se matter.' 
In effect the court refused to rule on how much harm to the child would be needed to counterbalance the weight given to parental decision-making as a factor in the child's best interests. Previous decisions by State courts are, then, still influential but, again, divided in their approach. On the one hand, a majority of the Kentucky court in King $v$ King Ky. affirmed the existence of grandparents' 'fundamental rights' ${ }^{\text {, }}$ and then went on to consider welfare. It upheld the constitutionality of the Kentucky grandparent visitation statute apparently because, since contact would promote social stability and, more importantly, the welfare of grandparents and grandchildren, ${ }^{126}$ the state had a legitimate interest in allowing it. In contrast, the Tennessee Supreme Court held that the visitation statute violated the Tennessee Constitution and refused even to entertain the question of whether grandparent vistation might be in the best interests of children absent 'substantial danger of harm to the child'. ${ }^{127}$

That the Supreme Court had previously expanded the concept of family privacy to embrace grandparents and grandchildren - on the basis of participation 'in the duties and the satisfactions of a common home, ${ }^{128}$ so that generally grandparents have to show a shared household for the purposes of 'mutual sustenance' 129 - is, then, not enough. Again, in the USA as in Europe, what is needed for success is a construction of welfare that gives significant weight to the benefits of contact.

\section{CONCLUSION}

It seems to us that the rights-talk generated by the HRA will not alone have the effect of encouraging the excluded extended family to seek involvement in children's lives or the nuclear family to accept it. Nor, it seems, will the courts be moved either to allow rights to trump ${ }^{130}$ welfare or to allow parental authority easily to be undermined by third parties. In a society where 
the paramountcy principle is hailed as the 'golden thread' that runs through its legisation dealing with children, where political and legal rhetoric has for decades proclaimed the overriding importance of children's interests, it is unlikely that the courts will relinquish the principle. In a clash between claims and counter-claims of rights, it is apparent from the jurisprudence of Europe, the USA and the UK that the welfare of children is a 'good' that all can agree on. The probability is that under the HRA only those rights of adults involved in disputes that correspond with current understandings of welfare will be upheld. And in cases of conflict the unity and autonomy of the nuclear family may be seen as most important for children’s welfare.

What would be more helpful to grandparents than rights would be the development of a body of expert knowledge that designated grandparent contact as having an important part to play in securing most children's well-being. Yet more recent research on the benefits of grandparentgrandchild contact, for example, is sparse and ambivalent and not sufficiently weighty to support such a conclusion. ${ }^{131}$ Government 'education' could be influential if the policy developments heralded by Supporting Families (Home Office, 1998) lead to the internalisation by professionals and parents of the importance to children of a wider kinship network. But until courts do conclude that contact by grandparents should, in general, be supported, their interests will be be subordinated to those of the nuclear family. Given that it is usually parents who undertake the day to day responsibilities for raising their children, perhaps that is as it should be. Any other outcome could result in what the Law Commission once referred to as 'rights without responsibilities'.

\section{NOTES}




\section{REFERENCES}

D. Archard, Rights and Childhood (London: Routledge, 1993).

A. Bainham '’Contact as a Fundamental Right' [1995] CLJ 255.

R. Bailey-Harris, G. Davis, J. Barron, and J. Pearce, Monitoring Private Law Applications Under the Children Act: A Research Report to the Nuffield Foundation, (University of Bristol, 1998).

A. Bainham (ed), 'Development of Family Law in Macedonia' in The International Survey of Family Law 1997 (The Hague: Martinus Nijhoff).

A. Barlow and S. Duncan, 'Supporting Families? New Labour’s Communitarianism and the “Rationality Mistake”, Journal of Social Welfare and Family Law (2000) 22(1) 23-42.

C. Barton 'When did you next see your father? Emigration and the one-parent family - Re T (Removal from Jurisdiction); Goertz v Gordon (formerly Goertz) [1997] CFLQ 73.

J Bohl 'Hawk v Hawk: An important step in the reform of grandparent vistation law' (1994-95) 33 U of Louisville J of Fam Law 55;

J Bohl 'Family Autonomy vs. Grandparent visitation: How precedent fell prey to sentiment in Herndon v. Tuhey' (1997) 62 Missouri Law Rev 755;

C. Bostock 'Does the expansion of grandparent visitation rights promote the best interests of the child? A survey of grandparent visitation laws in the fifty states' (1994) 27 Columbia J of Law and Social Problems 319.

B. Broad, 'Kinship Care, Children placed with extended families’ Childright (155) April 1999, 16.

R. Buxton, ‘The Human Rights Act and Private Law’ [2000] 116 Law Quarterly Review 48. 
R. Carne 'Grandparents and the Children Act 1989' [1996] Fam Law 416.

A. Cherlin, A. and F. Furstenberg, (The New American Grandparent: A Place in the Family, A Life Apart, (New York: Basic Books, 1986).

K. Czpanskiy, ‘Grandparents, parents and grandchildren: actualizing interdependency in law’ 26 Connecticut Law Review (1994) 1315.

H. Crook, ‘Grandparents and the Children Act 1989’ Family Law [1994] 135-138.

J. Dewar (2000) Family Law and its Discontents' International Journal of Law, Policy and the Family 14: 19-85.

A. Diduck and F. Kaganas, Family Law, Gender and the State (Oxford: Hart Publishing,1999). L.A. Drew and P.K. Smith, 'The Impact of Parental Separation/Divorce on GrandparentGrandchild Relationships' (1999) 48 Int'l J. Aging and Human Development 191-216.

G. Douglas and N. Lowe 'Grandparents and the Legal Process' 2 Journal of Social and Welfare Law (1990) 89-106.

J. Eekelaar, 'The Interests of the Child and the Child's Wishes: The Role of Dynamic SelfDeterminism’ 8 Int. J. Law \& Fam (1994) 42.

K.D. Ewing ‘Legislation: The Human Rights Act and Parliamentary Democracy’ (1999) 62 MLR 79.

J. Fortin, Children's Rights and the Developing Law (London: Butterworths, 1998).

J. Fortin, (1999a) 'Is Blood Really Thicker than Water? Re D’ [1999] CFLQ 435.

J. Fortin, (1999b) ‘The HRA’s impact on litigation involving children and their families’ (1999)

11(3) CFLQ 237

Grandparents’ Federation, Residence Order Allowance Survey: Report and Findings, (undated publication of inquiry conducted between November 1997 and May 1998).

R. Greeff, Fostering Kinship, (Aldershot: Ashgate Pub. Coy, 1999). 
D.J. Harris, M. O’Boyle and C. Warbrick Law of the European Convention on Human Rights (London: Butterworths, 1995)

M. Hayes and C. Williams, Family Law: Principles, Policy and Practice, (London: Butterworths, 1999).

J. Herring, (1999a) 'The Human Rights Act and the welfare principle in family law - conflicting or complementary?’ (1999) 11(3) CFLQ 223.

J. Herring (1999b) 'The Welfare Principle and the Rights of Parents'in A. Bainham, S. Day Sclater and M. Richards What is a Parent? (Oxford: Hart Publishing, 1999).

Home Office (1998) Supporting Families.

M. Hunt 'The “Horizontal Effect” of the Human Rights Act' [1998] PL 423.

Lord Irvine of Lairg 'The development of Human Rights in Britain under an incorporated Convention on Human Rights’ [1998] PL 22.

S. Jackson, (1999) 'Family Group Conferences and Youth Justice: The New Panacea?' in B. Goldson (ed) Youth Justice: Comtemporary Policy and Practice, (Aldershot: Ashgate).

The Hon. Sir John Laws ‘The Limitations of Human Rights’ [1998] PL 254.

F. Kaganas and C. Piper, 'Grandparents and the Limits of the Law' International Journal of Law and the Family (1990) 27-51.

F Kaganas (1999) 'Contact, Conflict and Risk' in S Day Sclater and C Piper (eds), Undercurrents of Divorce (Aldershot: Ashgate).

Karsten, I. 'Atypical Families and the Human Rights Act: The rights of Unmarried Fathers, Same Sex Couples and Transsexuals’ [1999] EHRLR 195, 195-6.

M. King “”Being Sensible”: Images and Practices of the New Family Lawyers’ 28(2) Journal of Social Policy, (1999) 249.

M. King, 'Welfare and Justice' in M. King, (Ed) Childhood, Welfare and Justice, (London: 
Batsford Academic Press, 1981).

M. King and C. Piper, How the Law Thinks About Children (2nd ed.) (Aldershot: Arena, 1995).

E. Kruk, ‘Grandparent Visitation Disputes: Multigenerational Approaches to Family Mediation’, 12(1) Mediation Quarterly (1994) 37

The Hon. Sir John Laws ‘The Limitations of Human Rights’ (1998) Public Law 254.

A. Lester and D. Pannick 'The Impact of the Human Rights Act on Private Law: The Knoght's Move’ [2000] 116 LQR 380

J. Liddy 'Current Topic: The Concept of Family Life under the ECHR' (1998) EHRLR 15.

G. Marshall ‘Comment: Interpreting interpretation in the Human Rights Bill’ [1998] PL 167.

J. Nichols 'Grandpa take me home: the unconstitutionality of the Michigan grandparent visitation statute under the due process clause’ (1996-7) Wayne Law Rev 1887.

D. Pannick 'Comment. Principles of interpretation of Convention rights under the Human Rights Act and the discretionary area of judgment' [1998] PL 545.

C. Piper ‘How Do You Define a Family Lawyer?’ 19(1) Legal Studies (1999) 93.

C. Piper 'Re O (Contact: Imposition of Conditions) [1995] 2 FLR 124, CA' (1995) 17 Journal of Social Welfare and Family Law 355.

H. Reece, 'The Paramouncy Principle: Consensus or Construct?’ 49 Current Legal Problems (1996) 267.

J Sinclair, The Law of Marriage, Vol 1 (Kenwyn: Juta \& Co, 1996).

R. Singh, M. Hunt and M. Demetriou 'Current Topic: Is there a Role for the "Margin of Appreciation” in National Law after the Human Rights Act?’ [1999] EHRLR 15.

C. Smart and B. Neale, Family Fragments? (Cambridge: Polity Press, 1999).

L. Spriovik-Trpenovska 'Development of Family Law in Macedonia' in A. Bainham (ed) The International Survey of Family Law 1997 (The Hague: Martinus Nijhoff, 1999). 
K. Starmer, European Human Rights Law (London: LAG, 1999).

H. Swindells, M. Kushner, A. Neaves and R. Skilbeck Family Law and the Human Rights Act 1998 (Bristol: Family Law, 1999)

N. Tingle Grandparents? - Who Needs Them? What It's Like Having Children in Care.

G.Van Bueren ‘Protecting Children’s Rights in Europe - A Test Case Strategy’ (1996) EHRLR 172.

J. Wadham. and H. Mountfield. Blackstone’s Guide to the Human Rights Act (1999).

H.W.R. Wade ‘Horizons of Horizontality’ \{2000) 116 LQR 217.

J. Walsh, Across the Generations, Age Concern Report into Grandparent/grandchild Relationships (London: Age Concern, 1998).

1. $\quad$ Troxel v Granville No. 99-138 [2000] affirming 137 Wash 2d 1, 969 P 2d 21, 99-138 (http:/supct.law.cornell.edu/supct/html/99-138).

2. $\quad \operatorname{Re~F~(Care:~termination~of~contact)~[2000]~} 2$ FCR 481; Lexis, 8 June 2000.

3. [2000] 1 FLR 263.

4. See, for example, Home Office (1998) paras 1.59 and 1.60.

5. In terms of the functions ascribed by American role theorists, a grandparent will be: 'historian, model, mentor, nurturer, and "great-parent" (an ultimate support person in family crises and transitions)’ (Kruk, 1994: 38).

6. For a critique of this policy approach, see Barlow and Duncan (2000).

7. The Constitution of the Republic of South Africa, 1996, s28(1)(b) provides that, 'Every child has the right ... to family care or parental care' [emphasis added], suggesting that the family is more than a parent/child unit. It is the case, however, that in South Africa definitional problems led to the abandonment of a provision in the Constitution protecting the 'family'. And it has been said that, despite the significance of the extended family, it is still the nuclear family that holds sway in South African law: see Sinclair (1996: 159, n422).

8. The Family Code, Art 2 provides that, 'The family is a community of life of parents and children, and other relatives if they live in a joint household'. As Spriovik-Trpenovska (1999: 239, 234) points out, however, the context for this 'transitional provision' is a 
constitutional duty on adult children to take care of elderly parents.

9. According to a Gallup Survey commissioned by Age Concern, 29\%, almost a third, of all adults in the UK are grandparents: see Walsh (1998).

10. Leading to what has been referred to in North America as the 'disengaged grandparent phenomenon' (Kruk, 1994: 38).

11. Broad (1999: 16-17); Greeff (1999). The experimental use of family group conferences in child protection and youth justice could also be seen as an acknowledgment of the importance of the wider family network: see, for example, Jackson (1999).

12. $50.7 \%$ of the 148 respondents to the questionnaire had sought a contact order (Drew and Smith, 1999: 205).

13. There are similar provisions in in legislation the Northern Ireland (Children) Order and Family Law Act (Scotland).

14. See ‘Grandparents Demand Access Rights’, Childright (April 2000: 12).

15. This is not to say that grandparents - and others - may not come within the other categories of persons who can make applications without leave, for example guardians: see s 10(4) and (5) and s 34(1).

16. A status which they briefly held in the UK as a result of the implementation of the Domestic Proceedings and Magistrates Court Act 1978 and the Children and Young Persons (Amendment) Act 1986: see Douglas and Lowe (1990: 89-93); Kaganas and Piper (1990: 29-30).

17. The first criterion - 'the nature of the proposed application ...' (section 10(9)(a)) is in practice 'closely inter-related'with the second (Hayes and Williams, 1999: 92).

18. See Crook (1994).The Law Commission Law Com. No 172, Family Law. Review of Child Law. Guardianship and Custody (London: HMSO, 1998) prior to the Act, had also expressed such optimism at para 4.41.

19. [1997] 1 FLR 793 at 795. For a similar approach in relation to care proceedings, see $R e$ $M$ (Care: Contact: Grandmother's Application for Leave) 2 FLR 86, 95. Indeed, the Children Act 1989 itself assumes contact between a child in care and 'any relative' is beneficial: see Schedule 2 para 15(1)(c) which imposes a duty to promote such contact. It is notable that in s105 of the Children Act 1989, 'relative' is defined to include stepparents but the definition does not include step-grandparents. They are increasingly a source of support for children but, it seems, the relatives of the biological nuclear family take precedence over those of the 'social' family.

20. A comment by the Minister of Health, David Mellor during the passage of the Children Bill (see Crook, 1994: 136). 
21. Re A and W (Minors) (Residence Order: Leave to Apply) [1992] 2 FLR 154.

22. See also Re A and Others (Minors)(Residence Order) [1992] 3 All ER 872; Re SC (A Minor)(Lea ve to Seek a Residence Order) [1994] 1 FLR 96. It appears that Johnson $\mathrm{J}$ in $\operatorname{Re} C(A$ Minor)(Lea ve to Seek Section 8 Orders) [1994] 1 FLR 26 erred on this point. But see $B v$ B

(Residence Order:

Restricting Application s) [1997] 1 FLR 139, 145 and $R e$ $P$ (Section 91(14) Guidelines) (Residence and

Religious Heritage) [1999] 2 FLR 573, 592 where it was held that s91(14) should be read in conjunction with s1(1). 
23. North Yorkshire County Council v G [1993] 2 FLR 732 and Re A (A Minor)(Residence Order: Leave to Apply) [1993] 1 FLR 425, 428.

24. $\quad$ Re A (Minors) (Residence Order) [1992] 3 All ER 872; see also Carne (1996: 416).

25. $\quad \operatorname{Re}$ A (A Minor) (Contact: Leave to Apply) [1995] 3FCR 543; JPN (1995) 722.

26. Re A (Section 8 Order: Grandparent Application) [1995] 2 FLR 153 at 157.

27. Idem.This principle was affirmed in relation to applications under section 34 of the Children Act 1989 (for contact with a child in care) in Re W (Contact: Application by Grandparent) [1997] 1 FLR 793 and also, in Re M (Care: Contact: Grandmother's Application for Leave) [1995] 2 FLR 86, when Ward LJ stated, 'The fact is that Parliament has refused to place grandparents in a special category or to accord them special treatment’ (at 95).

28. Re W (Contact Application: Procedure) n3 above, 269.

29. [1996] 1 FLR 158.

30. Czapnskiy (1994: 1335-56), draws attention to a similar much earlier case in the USA: Johansen v Lanphear 464 N.Y.S. 2d 301 (App. Div. 1983).

31. See, for example, Re A (Section 8 Order: Grandparent Application) [1995] 2 FLR 153; Re W(Contact: Application by Grandparent) [1997] 1 FLR 793. Compare the position of fathers seeking contact. See, for a review of such cases, Kaganas (1999).

32. This is a factor to which the court must have regard under s 10(9)(b) in determining applications for leave: Re W (Contact Application: Procedure) n3 above, 268.

33. $\quad$ Re A (Section 8 Order: Grandparent Application) [1995] 2 FLR 153.

34. It appears that the claim of a grandparent will not prevail over that of a natural parent unless there is evidence that the child will suffer severe harm as a result of living with the natural parent (Fortin, 1998: 347ff). The child is deemed to have a 'prima facie right' 'to an upbringing by its surviving parent' (Re K (a minor)(ward: care and control [1990] 3 All ER 795, 800) and Re W (A Minor) (Residence Order) [1993] 2 FLR 625 reveals how strong the non-parent's case has to be to override this right. See also Re D (Care: Natural Parent Presumption) [1999] 1 FLR 134 where the court interpreted the 'natural side of the family' to mean the 'natural parent': there was no weight placed by the local authority or the court on the grandmother's own blood tie with her grandson (Fortin, 1999a).

35. For details of this research see King (1999); Piper (1999). See also, for earlier research, Lowe and Douglas (1990: 95); Kaganas and Piper (1990).

36. See, for example, Swindells et al (1999: 54); Wadham and Mountfield (1999). 
37. For the position generally in the USA see Bostock (1994); see also Nichols (1996-7).

38. See also Herring (1999b).

39. For an early critique of the dichotomy see King (1981).

40. $\quad$ See King and Piper (1995: Chapter 1).

41. See, for example, Eekelaar (1994); Archard (1993: Chapter 4).

42. In a different context the welfare v justice debate has been given a new slant as a result of a recent development in sociological theory in relation to private family law; some feminist writing is beginning to theorise about contact with children by juxtaposing an ethic of care against an ethic of justice. See Smart and Neale (1999), especially chapters 8 and 9.

43. Indeed a Court of Appeal judge, Buxton LJ, has expressed doubts as to whether the Convention (and so presumably the HRA) is relevant in private law intra-familial disputes (Re A (Permission to Remove Child from Jurisdiction: Human Rights) [2000] 2 FLR 225, 229).

44. The Court and the Commission have been concerned to develop the case law to take account of social change: see Karsten (1999).

45. Marckx $v$ Belgium (1979) 2 EHRR 330, para 31. Respect for family life may entail the 'adoption of measures designed to secure respect ... even in the sphere of the relations of individuals between themselves' ( $X$ and $Y$ v Netherlands (1985) 8 EHRR 235, para 23).

46. Provided the de facto relationship between the unmarried parents has been a stable one (Karsten, 1999: 198): see Keegan v Ireland (1994) 18 EHRR 342, para 45; Kroon $v$ The Netherlands (1995) 19 EHRR 263. The Court in Kroon (para 30), and the Commission in Price v United Kingdom, 9 March 1988, Application No 12402/86, 55 DR 224, 234, ruled that in general, living together may be a requirement for family life but that other factors may show a sufficient degreee of constancy. In Soderback v Sweden (1998) 3 EHRLR 342, it appears to have sufficed, although the father did not live with the child, that he showed some commitment to contact.

47. See, for example, Berrehab v The Netherlands (1989) 11 EHRR 322, para 21.

48. $\quad$ McMichael $v$ United Kingdom (1995) 20 EHRR 205 para 86; $B v$ United Kingdom (1988) 10 EHRR 87. See also $X$ v The Netherlands, Application 8427/78, 13 March 1980, 18 DR 225; Keegan v Ireland n46 para 44 .

49. Marckx above n45, para 45.

50. Ibid, para 52

51. S and S v United Kingdom 10 Dec 1984, Application No10375/83, 40 DR 196. See also, in relation to the requirement of closeness and dependency in the context of grandparents 
and grandchildren, the comments of the Commission in $X, Y$ and $Z \mathrm{v}$ United Kingdom [1997] 24 EHRR 143, para 52.

52. $\quad X v$ Switzerland 10 March 1981, Application No8924/80, 24 DR 183.

53. Price v United Kingdom, above n46. See also Boyle v United Kingdom (1994) 19 EHRR 179.

54. (1988) 11 EHRR 175 para 61. This decision has been criticised (see Van Bueren, 1996).

55. $\quad$ See also $R v$ United Kingdom (1988) 10 EHRR 74 para 64.

56. See also $X$ and $Y$ v The Netherlands, Application No 6753/74, 19 Dec 1974, 2 DR 118. On divorce, neither parent has a greater right than the other and the competent authority must make a decision taking into account the best interests of the child ( $W v$ Federal Republic of Germany, Application No 11526/85, 10 Oct 1986, 50 DR 219). A decision, for example, to move the child from one parent to the other constitutes an interference with the latter's right to family life. But it will be legitimate provided it complies with Art 8(2) (Hoffmann v Austria (1994) 17 EHRR 293).

57. Price $v$ United Kingdom, above n46, and Lawlor v United Kingdom, 14 July 1988, Application No12763/87, 57 DR 216.

58. $\quad$ Price $v$ United Kingdom, above n46, 235.

59. Ibid, 237.

60. $\quad$ Price v United Kingdom, ibid, 236.

61. See $X v$ France, 5 October 1982, Application No9993/82, 31 DR 241; $L v$ Sweden, Application No 10141/82, 3 Oct 198440 DR 140; AR v Austria, 4 March 1987, http://www.dhcour.coe.fr/hudoc/; $B \quad v$ United Kingdom 26 May 1987 http://www.dhcour.coe.fr/hudoc/; Eriksson v Sweden (1990) 12 EHRR 183 paras 66-7; Olsson v Sweden (No 2) (1993) 17 EHRR 134 paras 83-90; Hoffmann v Austria (1994) 17 EHRR 293 para 34; Hokkanen v Finland (1995) 19 EHRR 139, para 58; Soderback v Sweden [1999] 1 FLR 250.

62. (1996) 23 EHRR 33 para 78. See also $L v$ Finland [2000] 2 FLR 118, 140; K and T v Finland [2000] 2 FLR 79, 107; Elsholz v Germany [2000] 2 FLR 486, 497.

63. Hokkanen $v$ Finland (1995) 19 EHRR 139.

64. Ibid, para 58.

65. Keegan $v$ Ireland above $\mathrm{n} 46$ paras 49 and 55.

66. See also K and T v Finland [2000] 2 FLR 79 at 101. 
67. Ibid at 112.

68. [2000] Fam Law 880.

69. Hokkanen v Finland above n63 paras 61-2.

70. Ibid, para 64 .

71. See Keegan $v$ Ireland above $n 46$. See also $K$ and $T$ v Finland above n66. Compare $L \mathrm{v}$ Finland [2000] 2 FLR 118.

72. See Hokkanen v Finland above, n63 para 62.

73. (1995) 20 EHRR 205, para 98.

74. See also B v UK [2000] 1 FLR 1 where the Court appears to have found differential treatment of fathers without parental responsibility justified on what appears to be the assumption that those with parental responsibility are more likely to be caring for children and that they are therefore entitled to greater rights.

75. $\quad$ Ashingdane v UK (1984) 7 EHRR 528.

76. Section 6(1).

77. As defined in s1.

78. Section 6(2)(a).

79. Section 3(1).

80. Section 6(3)(a).

81. 'By making courts and tribunals "public authorities" it imposes a duty on them to act compatibly with the Convention' (Hunt, 1998: 440). See also the view of the Lord Chancellor, HL Deb November 241997 col 783. It appears that Convention rights `may be relied upon in litigation between private parties but cannot themselves be the basis of a cause of action' (Ewing, 1999: 89).

82. The Act does not create a new cause of action in litigation between private individuals; there is no new tort of 'breach of the Convention' (Wadham and Mountfield, 1999: 26). The Convention can be invoked against a private individual only to the extent that there is an existing statutory or common law right which can be interpreted so as to accord with the Convention, or where there is judicial discretion which can be exercised to give effect to a Convention right (Wadham and Mountfield, 1999: 26). Human rights will come to be 'woven' into the common law (Lester and Pannick, 2000: 385). However, in cases where the act complained of is private, it is only when it 'is done under colour of law' and where the State has a duty to protect the rights of one of the parties as against the other that it will be held to contravene the HRA. See, for debate on the issue of 
horizontality also Wade (2000) and Buxton (2000).

83. Section 2.

84. The applicability of concepts such as the 'margin of appreciation' in domestic courts remains contentious. See, for example, Singh et al (1999); Pannick (1998).

85. Bringing Rights Home: The Human Rights Bill, Cm 3782 (1997: para 2.4).

86. Notwithstanding that English law tends to define 'family' in terms of the nuclear family: see Diduck and Kaganas (1999: 31). Neither Fortin (1999b) nor Herring (1999a) in their discussions of Art 8 and the Human Rights Act refer to the extended family as falling within the purview of 'family life'.

87. What follows is based on Hunt's analysis (1998: 442) of the operation of the Act.

88. Above, n3 at 269.

89. In relation to fathers, it has been said that contact is 'almost always' in children's best interests; see for example, Piper (1995).

90. See, for an overview, Drew and Smith (1999).

91. Similarly, parents and children could challenge a decision, granting contact to other relatives for example, as being unlawful on the grounds that the court has failed to interpret the Children Act and the relevant case law in a way that gives effect to their rights to family life.

92. In the case of an application made by a child, the child's best interests, although not paramount, have been said to be significant and in such cases s10(9) does not apply: Re C (Residence: Child's Application for Leave) [1995] 1 FLR 927, 931.

93. However, given that s1(3) is located under the general heading 'Welfare of the Child', courts may well regard only the child's right to family life as being relevant under that provision.

94. A version of the concept of proportionality has already made an appearance in cases dealing with the imposition of a leave restriction under s91(14). In Re P (Section 91(194) Guidelines)(Residence and Religious Heritage) [1999] 2 FLR 573, 593, the Court of Appeal stated that the court must weigh in the balance all the circumstances, that it may impose a restriction where the welfare of the child demands it, but that the degree of restriction should be proportionate to the harm it is intended to avoid. See also the balancing exercise undertaken by the court in Re W(Contact Application: Procedure) n3 above.

95. See, for example, Price $v$ United Kingdom where the commission considered that to secure the child's 'emotional security' as well as physical safety was necessary in a 
democratic society; There was a pressing social need to protect the child's health and rights which justified the Local Authority's interference with the grandparents' rights to family life by terminating access (n46 above, at 236).

96. This approach gains some support from the decision in Re $P$ (Section 91(14) Guidelines)(Residence and Religious Heritage) [1999] 2 FLR 573 n22. There it was held that the the court's discretionary power to impose leave restrictions under s91(14) did not contravene Arts 6(1) or 9 of the Convention or the provisions of the Human Rights Act. Although Art 8 was not referred to, the court clearly regarded it as legitimate to refuse leave where the application is hopeless in order to protect the other parties and the child from involvement in the proceedings and unwarranted investigation of the chid.

97. Ss1(3) and 1(1) respectively.

98. [1970] AC 668, 710-11.

99. $\quad$ See the above discussion of Johansen $v$ Norway and Hokkanen $v$ Finland.

100. Compare the cases on emigration by the caretaking parent after divorce, where the paramountcy principle does not operate and the courts do not always distinguish clearly between rights and welfare. On this see Barton (1997). But see Re A n43 where Ward $\mathrm{LJ}$ distinguished clearly between the rights of the father and child to family life and the mother's right to freedom to live her private life as she wished (p. 227).

101. But see Reece (1996), who argues that the paramountcy principle is not essential to the protection of children's welfare.

102. See Hokkanen v Finland where the European Court, although it referred to the need to strike a fair balance, accepted, on the strength of expert evidence, that the child's interests in remaining with her grandparents sufficed for the purposes of Art 8(2) in a jurisdiction that emphasised children's welfare. Finland had not overstepped the margin of appreciation (above, n63 para 64). See also Wv Federal Republic of Germany 10 Oct 1986, Application No 11526/85, 50 DR 219.

103. Glaser v UK above n68.

104. Re M (Contact Order: Committal) [1999] 1 FLR 810, 825.

105. Ibid 826-7.

106. [1999] 1 FLR 1167, 1182.

107. [1999] 2 FLR 678, 700.

108. However where both parents have identical rights, he said obiter, there is no difficulty in imposing limitations on the right of one parent where it conflicted with the rights of the other parent or the child and was not in the child's best interests. 
109. [1998] 1 All ER 577.

110. At 587.

111. At 588.

112. Re P (Section 91(14) Guidelines (Residence and Religious Heritage), above, 599. See also Re L (Contact: Domestic Violence); Re V (Contact: Domestic Violence); Re M (Contact: Domestic Violence); Re H (Contact: Domestic Violence) [2000] 2 FLR 334 (forthcoming), where Butler-Sloss P invoked European case law in support of the contention that the interests of the child had to prevail under Art 8(2).

113. Admittedly, there are some cases where a pure balancing exercise could lead to a different outcome from the application of the Children Act. This would occur, for example, in cases where the evidence is neutral as regards the welfare of the child. The so-called 'no order' principle as it was applied in Dawson $v$ Wearmouth requires evidence of some benefit to the child. The court requires 'some evidence that [the order] would lead to an improvement from the point of view of the welfare of the child' (above, n106 1171). It is not clear how this would interact with the Convention. Whereas under the Convention and the HRA, a decision would be made in the basis of a balancing exercise of all the individuals' interests, under the welfare/no order principles of the Children Act, the remedy sought would simply be denied.

114. (1987) 10 EHRR 29 para 74.

115. This view assumes, with justification, it is submitted, that the paramountcy principle satisfies the necessity and proportionality tests.

116. [1998] 1 FLR 762.

117. At $775-6$.

118. Abdulaziz v UK (1985) 7 EHRR 471; Berrehab v Netherlands, above n47; Poku v United Kingdom (1996) EHRR CD 94.

119. Abdulaziz above, para 67.

120. [1998] 1 FLR 762, 788. Indeed Buxton LJ in Re A (above n43) said that there is a difference between intra family disputes and those where there is a clash between the family as a whole and a 'national, economic or political entity' and doubted that the Convention was relevant to the former category (at 229).

121. See also Pierce $v$ Society of Sisters, 268 U.S. 510, $534-535$ (1925); Prince $v$ Massachusetts, 321 U.S. 158 (1944); Wisconsin v Yoder 32 L.Ed.2d 15 (1972). O’Connor J refers to further relevant cases in Troxel $v$ Granville (above $\mathrm{n} 1$ ).

122. 442 U.S. at 602.

123. Stevens, J., dissenting, did not accept that the Supreme Court's jurisprudence established 
'a rigid constitutional shield' for parents: 'even a fit parent is capable of treating a child like a mere possession'.

124. See, for example, Cal. Fam. Code. Ann s3104(e) (West, 1994).

125. 828 S.W.2d 630.

126. Both grounds are cited with approval in Herndon v Tuhey 857 S.W.2d 203 (Mo. banc 1993) 209-10. See Bohl (1997).

127. Hawk v Hawk 855 S.W.2d 573 (Tenn 1993). See Bohl 1994-5.

128. In Moore v East Cleveland 52 L.Ed.2d 531 (1977), 541-2, the court found that a housing ordinance defining 'family' as parents and their children 'deeply intrude[d] into family associational rights' (544).

129. Ibid, 540 .

130. We are, then, qualifying John Dewar's recent comment that 'the whole point about rights' is 'that they cannot be "trumped” by other considerations' (2000: 72).

131. Kruk's review (1994) of 27 relevant American texts includes 17 published before 1986 and 4 after 1989. Cherlin and Furstenberg (1986: 172-84), for example, found no measurable long term positive effects on grandchildren - over a range of indicators stemming from grandparent involvement in their lives. See also Kaganas and Piper (1990: 27-9, 32-4). 